\title{
Effect of Ag nanoparticles on viability of MCF-7 and Vero cell lines and gene expression of apoptotic genes
}

\author{
Maryam Hassan Sangour ${ }^{1}$, Iftikhar M. Ali ${ }^{2}$, Zeenah Weheed Atwan ${ }^{1 *}$ and Ali Abd Al Lateef A. Al Ali ${ }^{3}$
}

\begin{abstract}
Background: The newly emerged technology, nanotechnology, represents a promising solution for many medical and industrial problems. Random targeting, resistance, and side effects are the main disadvantages of the available cancer chemotherapy which are critical aspects needed to be managed. So the aim of the study was to suggest the nanoparticles as an alternative therapy for the available therapies through detecting the cytotoxic effect of Ag nanoparticles against cancer and normal cell lines and how they affect the apoptotic function and the genes involved.
\end{abstract}

Results: Ag NPs exhibited a killing rate of 40\% in MCF-7 cells (the cancer cell model) at a concentration of $100 \mu \mathrm{g} /$ $\mathrm{ml}$ with almost no effect on Vero cells (the normal cell model). Concerning the phenotypic apoptotic changes that were analyzed by Acridine orange and eosin and hematoxylin, Ag NPs caused the apoptosis and Vacuole degeneration as well as cell formation and the emergence of Necrotic cells in MCF-7 cells, whereas in the normal cell line Vero, no change appears in its phenotype.

Treating MCF-7 and Vero cells with Ag NPs upregulated the P53 and P21 gene expression in Vero cells, but their expression was downregulated in MCF-7 cells. PTEN was augmented in both MCF-7 and Vero cells compared to the control.

Conclusions: The AgNPs displayed selective effect in their cytotoxicity and both induced the apoptosis effect and might be suggested as a potential therapy since an increase in PTEN expression (up to 250-fold more compared to the control) due to the treatment with AgNPs augments the tumor suppressor effects of the PTEN.

Keywords: AgNPs, ZnS-Ag NPs, Apoptosis, P53 PTEN

\section{Background}

Cancer is a fatal disease that is initiated by environmental factors to mutate genes that are involved in regulating the cell growth. It is characterized by uncontrolled growth of cells, where the behavior of abnormal cells destroys the surrounding tissues [1]. The traditional methods of treating cancer are surgery, radiotherapy,

\footnotetext{
* Correspondence: za_zeenah@yahoo.com

Importance: The study introduced prepared nanoparticles with selective antitumor effect that increased the expression of the tumor suppressor proteins inside the cancer cells which suggests the possibility of using these nanoparticles in cancer treatment.

${ }^{1}$ Biology Department, College of Science, University of Basrah, Basra, Iraq Full list of author information is available at the end of the article
}

immunotherapy, hormonal therapy, and chemotherapy [2], but these treatments randomly target the tumor and cause undesirable side effects [3]. So, efforts were made to find alternatives such as nanoparticles. Nanoparticles or dwarfs " in Latin" are materials that do not exceed $100 \mathrm{~nm}$ in their sizes [4]. Nanotechnology offers a new approach to treat cancer since it carries the potential to reduce systemic toxicity by developing functional molecules as directed treatment chemically or biosynthesized such as Fe3O4/Ag nanocomposite. It also provides an alternative strategy to circumvent the resistance to multiple drugs including antibiotics, such as using the biologically synthesized $\mathrm{CuFe}_{2} \mathrm{O}_{4} @ \mathrm{Ag}$ nanocomposite 
[5-9]. Very small size, large surface area to mass ratio, and high reactivity, these properties make it important in designing high-precision materials and overcoming barriers in diagnostic and therapeutic factors [10]. Silver nanoparticles (Ag NPs) were used due to their unique properties and known effects in cancer treatment [11, 12]. Ag NPs have many applications in the field of medicine such as antibacterial agents, drug delivery vectors, and physical treatment agents. They have the ability to induce oxidative stress, mitochondrial membrane change, cell death by apoptosis, DNA damage, and cytokine production [13]. Various kinds of toxicity have been detected after exposure to nanoparticles such as changes associated with oxidative stress such as apoptosis, gene expression changes, and lipid oxidation [14].

So the aim of this study was to analyze the effect of AgNPs on cytotoxicity of cells and effect on genes implicated in apoptosis P53, P21, and PTEN.

\section{Methods}

\section{Effect of nanoparticles on the growth of cell lines}

Nanoparticles were prepared in distilled water using laser beam and were characterized by TEM and UV absorbance. The cytotoxic effect of nanoparticles was performed according to [15]. Confluent Vero (as a model for normal cells) and MCF-7 (as a cancer cell line) monolayers were simultaneously trypsinized as described above, and then, the suspensions were adjusted to a concentration of 10,000 cell $/ \mathrm{ml}$ in the growth medium. The cells were then seeded in 96-well plates at a volume of $100 \mu \mathrm{l}$ in each well and $\mathrm{i}$ the cells at $37^{\circ} \mathrm{C}$ were incubated for $24 \mathrm{~h}$ then were treated with Ag NPs at serial concentrations of $12.5,25$, and $100 \mu \mathrm{g} / \mathrm{ml}$.

The plates were incubated for $48 \mathrm{~h}$, after which the media and nanomaterials were removed. MTT staining was performed by adding $10 \mu \mathrm{g} / \mathrm{ml}$ of MTT in each well and $90 \mu \mathrm{l}$ of the media-free serum; the plates were again incubated for $1.5-3 \mathrm{~h}$. After incubation, MTT was removed and $100 \mu \mathrm{l}$ of DMSO was added instead for 20 min in the dark; finally, the absorbance was taken at $490 \mathrm{~nm}$ using ELISA. Reader and the cytotoxicity was calculated as follows:

$$
\text { Cytotoxicity }=(\mathrm{A}-\mathrm{B}) / \mathrm{A} \times 100
$$

where $A$ was the mean optical density of control well and $B$ was the optical density of treatment well.

\section{Morphological characterization of cell death Eosin and hematoxylin stain}

The confluent monolayer cells were plated in 6-well plate containing coverslips within each well and incubated for $24 \mathrm{~h}$. The coverslip-growing cells were treated with nanoparticles and then incubated for $48 \mathrm{~h}$ to allow
Table 1 The reaction components of cDNA synthesis

\begin{tabular}{ll}
\hline Material & Size \\
\hline Oligo dT 20 & $1 \mu \mathrm{l}$ \\
Template RNA & $5 \mu \mathrm{l}$ \\
Free DEPEC-D.W & $14 \mu \mathrm{l}$ \\
Final volume & $20 \mu \mathrm{l}$ \\
\hline
\end{tabular}

enough time for the material to inhibit or kill the cells, and then, the staining was achieved according to [16].

\section{Acridine orange stain}

Dissolve $1 \mu \mathrm{g}$ of orange acridine and $1 \mu \mathrm{g}$ of ethidium bromide with $10 \mathrm{~mL}$ of PBS, making the prepared concentration $1 \%$. The dye is prepared under dark conditions and at room temperature. Next, stain cover slid [17].

\section{Agarose gel electrophoresis}

DNA was visualized by $1.5 \%$ agarose gel electrophoresis stained with ethidium bromide according to SiZer ${ }^{\mathrm{n}}$ DNA Markers.

\section{Converting RNA to CDNA from cell line}

To convert RNA to cDNA, Accupower RocketScript ${ }^{R T}$ Premix from Bioneer, CA, K-2101, was employed relying on reverse transcriptase enzymes.

\section{Protocol}

RNA templates were extracted from cell line converted into complementary DNA (cDNA). The kit components were added to the reaction mixture and completed to a final volume of $20 \mathrm{ml}$ according to Accupower RocketScript ${ }^{\text {RT }}$ Premix from Bioneer instruction as shown in Tables 1 and 2.

\section{qPCR primers}

Sequences of PTEN, P21, P53, and $\beta$-actin primers that were used in real-time PCR to evaluate gene expression are shown in Table 3.

\section{Preparation of the real-time PCR reaction}

To prepare real-time PCR reaction, RealMOD ${ }^{\mathrm{mm}}$ Green SF 2X qPCR mix from iNtRON kit was used. The reaction was set according to instruction enclosed with RealM$\mathrm{OD}^{\mathrm{m}}{ }^{\mathrm{m}} \mathrm{Green}$ SF $2 \mathrm{X}$ qPCR mix from iNtRON kit. Then,

Table 2 Thermal cycling of cDNA synthesis (reverse transcriptase)

\begin{tabular}{lll}
\hline Step & Temperature & Time \\
\hline Primer annealing ( oligo dT 20) & 25 & $10 \mathrm{~min}$ \\
CDNA synthesis & 45 & $60 \mathrm{~min}$ \\
Heat inactivation & 95 & $5 \mathrm{~min}$ \\
\hline
\end{tabular}


Table 3 QPCR primers

\begin{tabular}{|c|c|c|c|c|c|}
\hline Gene & Sequence & & $\mathrm{Tm}$ & Product size & Reference \\
\hline \multirow[t]{2}{*}{ PTEN } & For. & 5'-AAG GCA CAA GAG GCC CTA GAT TTC T-3' & 60.0 & $148 \mathrm{bp}$ & {$[18]$} \\
\hline & Rev. & 5'-ACT GAG GAT TGC AAG TTC CGC CA-3' & 61.2 & & \\
\hline \multirow[t]{2}{*}{ P21 } & For. & 5'-TGG AGA CTC TCA GGG TCG AAA-3' & 61.3 & $143 \mathrm{bp}$ & [19] \\
\hline & Rev. & 5'-GGC GTT TGG AGT GGT AGA AAT-3' & 62.1 & & \\
\hline \multirow[t]{2}{*}{ P53 } & For. & 5'-CAGTTCCTGCATGGGGGGGGGGGGA-3' & & & {$[20]$} \\
\hline & Rev. & 5'-CGCCGGTCTCTCCCAGGACAGGACA-3' & & & \\
\hline \multirow[t]{2}{*}{$\beta$-actin } & For. & 5'-CCTGGCACCCAGCACAAT-3' & 58.4 & $138 \mathrm{bp}$ & [21] \\
\hline & Rev. & 5'-GCCGATCCACACGGAGTACT-3' & 62.5 & & \\
\hline
\end{tabular}

the reaction was conducted by PCR reaction condition (Tables 4 and 5).

\section{Result}

\section{Ag NPs}

AgNPs' characterization results are provided as supplementary 1. In order to evaluate the cytotoxic effect of the prepared AgNps on the viability of MCF-7 and Vero cells, the cells were left to grow in RPMI 1640 media for $24 \mathrm{~h}$ and then treated with $(12.5,25,100 \mu \mathrm{g} / \mathrm{ml})$ of AgNPs for $48 \mathrm{~h}$. The viability of MCF7 cells was assessed by MTT staining of treated or control samples and the absorbance was detected at $490 \mathrm{~nm}$. MCF-7 viability was clearly reduced in a dose-dependent manner since the viability decreased to $60 \%$ when the concentration was increased to $100 \mu \mathrm{g} / \mathrm{ml}$. In contrast, AgNPs exhibited almost no effect on viability of Vero cells at $100 \mu \mathrm{g} / \mathrm{ml}$ (Fig. 1). To summarize, AgNPs showed an activity that discriminates between cell lines and the aneuploidy cells and cancer cells.

\section{Effect of nanoparticles on morphology of Vero and MCF-7 cells}

The morphological effect of the prepared nanoparticles on Vero and MCF-7 cells was detected by Acridine orange and eosin and hematoxylin staining under fluorescent and light microscope. Vero and MCF-7 cells were grown in RPMI 1640 with $10 \%$ FBS media for $24 \mathrm{~h}$ and then treated with $100 \mu \mathrm{g} / \mathrm{ml}$ of $\mathrm{Ag}$ for $42 \mathrm{~h}$. Acridine

Table 4 Components of real-time PCR reaction

\begin{tabular}{ll}
\hline Materials & Size \\
\hline RealMODTMGreen SF 2X 9PCR mix & $10 \mu l$ \\
Forward for (PTENT, P21, P53, NF-KB, and B-actin) & $1 \mu \mathrm{l}$ \\
Revers for (PTENT, P21, P53, NF-KB, and B-actin) & $1 \mu \mathrm{l}$ \\
Nuclease free water & $7 \mu \mathrm{l}$ \\
Template CDNA & $2 \mu \mathrm{l}$ \\
Final size & $21 \mu \mathrm{l}$ \\
\hline
\end{tabular}

orange was used to stain cells, and morphological changes were traced in comparison with the control molecular layer. Treatment with AgNPs made the nuclei smaller (Figs. 2, 3, 4, and 5).

\section{Effect of nanoparticles on genomic DNA (DNA fragmentation test)}

Effect of the tested nanoparticles on genomic DNA of different cell lines was analyzed by agarose gel staining. MCF-7 and Vero cells were treated with $100 \mu \mathrm{g} / \mathrm{ml}$ of Ag NPs for $48 \mathrm{~h}$; then, the genomic DNA of each treated sample was loaded on agarose. Obviously, the control MCF-7 genomic DNA showed intense, sharp, and larger band compared to the Ag-treated DNA at $100 \mu \mathrm{g} / \mathrm{ml}$ (Fig. 6).

\section{P53 relative expression in Vero and MCF-7 cells}

In order to evaluate the P53 gene expression in Vero and MCF-7 cells, RNA samples that were extracted from cells treated with Ag NPS and were reverse transcribed to make the first strand of DNA were used as the templates. cDNA template was mixed with primers amplifying P53 to measure its gene expression using qPCR SYBR green. AgNPs exhibited a very different outcome on P53 expression; the treated Vero showed the highest expression followed by the control MCF-7, treated MCF-7, and the control Vero respectively (Fig. 7).

\section{P21 gene expression in Vero and MCF-7 cells}

Given the important role of $P 21$ in suppressing cancer cells, again cDNA from total RNA was made from cells treated with AgNPs and used as templates for relative gene expression assay normalized to the control genes. P21 expression was upregulated due to treating Vero cells while its level in untreated Vero or both treated and untreated MCF-7 cells was the same (Fig. 8).

\section{PTEN gene expression in Vero and MCF-7}

Due to the position of PTEN gene as one of the most tumor suppressor genes missing in cancer cells, PTEN 
Table 5 Real-time PCR program

\begin{tabular}{lllll}
\hline No. & Steps & Temperature & Time & No. of cycles \\
\hline I & Denaturation 1 & $94^{\circ} \mathrm{C}$ & $3 \mathrm{~min}$ & 1 \\
II & Denaturation & $94^{\circ} \mathrm{C}$ & $30 \mathrm{~s}$ & 40 \\
III & Annealing & $60^{\circ} \mathrm{C}$ & $30 \mathrm{~s}$ & \\
IV & Extension 1 & $72^{\circ} \mathrm{C}$ & $1 \mathrm{~min}$ & \\
V & Extension 2 & $72^{\circ} \mathrm{C}$ & $5 \mathrm{~min}$ & 1 \\
\hline
\end{tabular}

mRNA expression was evaluated in both treated and untreated. AgNPs treatment enhanced the expression of PTEN in both cell lines compared to its level in the corresponding controls (Fig. 9).

\section{Discussion}

\section{Effect of Ag NPs on cell lines}

The cells were treated with a series of concentrations of AgNPs for $48 \mathrm{~h}$. The results showed that the cell survival rate declines with the increasing concentrations of Ag NPs in MCF-7 cell line. This is consistent with [22-24] when HeLa cells are treated with plant-manufactured silver nanoparticles. However, MCF-7 shows the lowest sensitivity for treatment with AgNPs compared to other cell lines [25]. Silver nanoparticles show their toxicity through induction of oxidative stress by generating reactive oxygen species $[26,27]$.

Increasing level of ROS creates oxidative stress inside the cells and consequently leads to cell death through programmed cell death [28]. In addition, increased ROS levels may cause mitochondrial membrane damage and consequently leads to programmed cell death [29, 30]. In HeLa cells, cells treated with Ag NPs face death due to the decreased glutathione levels and the increase in the level of lipid peroxide, which in turn kills the cells due to the oxidative stress response [31, 32]. Another critical effect of Ag NPs is the accumulation of silver nanoparticles in the nucleus of GBM cells which leads to instability of chromosomes and mitosis. Ag NPs interfere with the structure of cellular actin which eventually kills the cells [31]. Mitochondria-dependent apoptosis can also be triggered by treatment with Ag NPs. Ag NPs can dissociate ions, hence disrupting the mitochondria membranes releasing cytochrome to the cytoplasm [31, 33, 34]. Ag NPs may also exhibit its effect on cancer cells through the physical-chemical interaction of the cellular proteins with the nanoparticles [35].

\section{Morphological analysis of nanoparticle effect on cell lines (apoptosis detection)}

Changes in cell morphology of Vero and MCF-7 cells and detection of apoptosis signs were investigated by Acridine orange at $25 \mu \mathrm{g} / \mathrm{ml}$ of Ag NPs for $48 \mathrm{~h}$. The was detected as apoptosis or necrosis compared with the untreated controls. Ag NPs did not show any phenotypic changes in Acridine orange, revealing that these substances do not affect the normal cells, whereas treating MCF-7 cells with the same particles created phenotypic changes such as apoptosis, vacuole degeneration, change in shape of some cells to rod shape, and necrotic cells (enlarged).

Breast cancer cells treated with Ag NPs show several morphological symptoms that can be easily under inverted microscope. Most of the cellular contents are condensed and take a position at one side of the cells, larger cytoplasm and have a granulus appearance. Attached cells tend to look rounded and others become loose since the junctions among them become weaker [36]. Ag NPs-A549-treated cells for 72

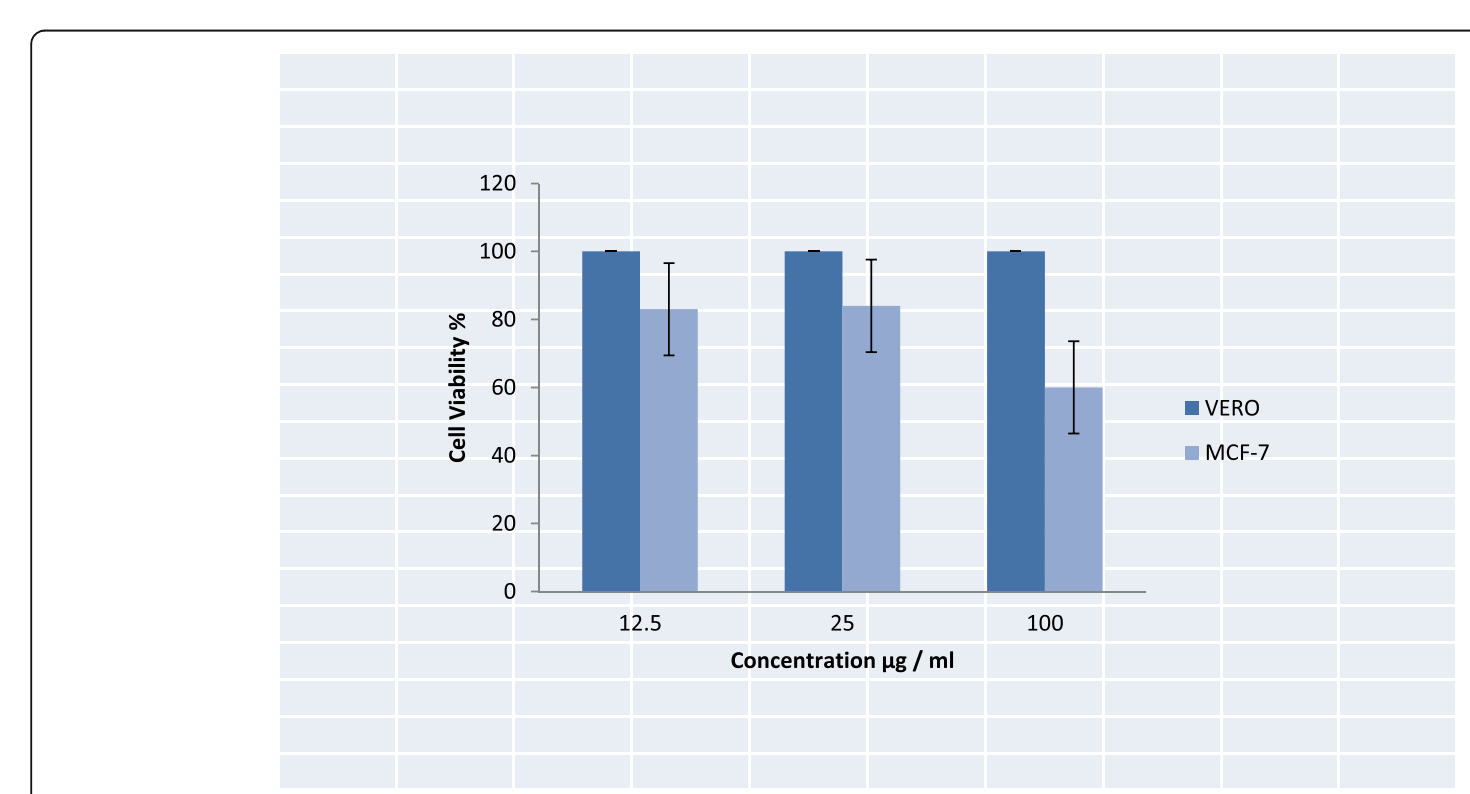

Fig. 1 Cytotoxicity of Ag NPs. Effect of AgNPs on viability of MCF7 and Vero cell lines. Cells were seeded at $37^{\circ} \mathrm{C}$ for $24 \mathrm{~h}$ prior to treatment with AgNPs. Cells were either treated with $(12.5,25,100 \mu \mathrm{g} / \mathrm{ml})$ of AgNPs for $48 \mathrm{~h}$ or treated with DMSO only as control. Cell viability was measured with MTT assay 

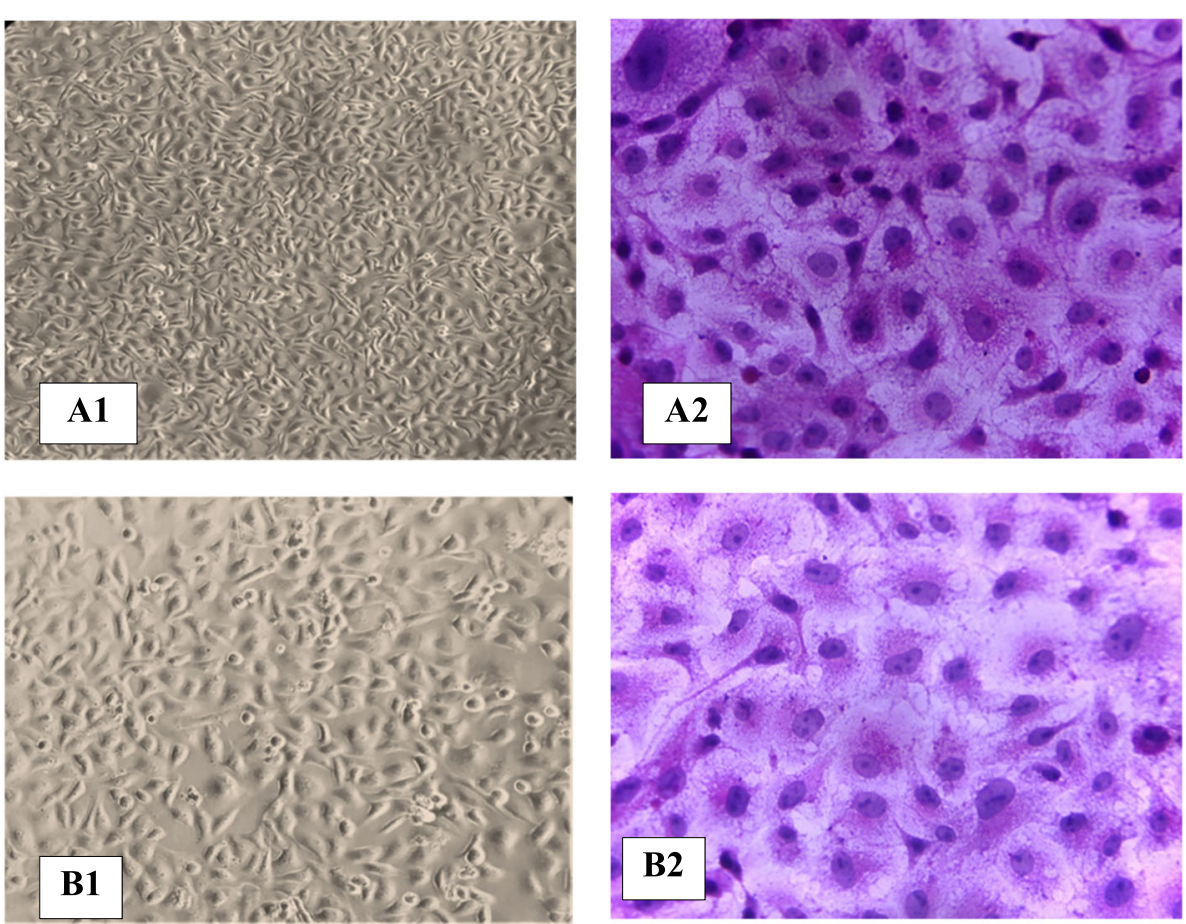

Fig. 2 Effect of nanoparticles on morphology of Vero and MCF-7cells. Hematoxylin and eosin of Vero cell line after 42 h. A1 unstained control confluent monolayer. A2 Stained control confluent monolayer. B1 unstained cells treated with $100 \mu \mathrm{g} / \mathrm{ml}$ of Ag NPS pure. B2 stained cells treated with $100 \mathrm{mg} / \mathrm{ml}$ of Ag NPS

h show typical apoptotic features such as condensed nuclei, membrane blabbing, and apoptotic fragments [37, 38].

Morphology of HeLa cells is affected with the exposure to AgNPs since they lose their regular shape with shrank edges, loosen adhesions, more dead floating cells, and decreased cellular density which suggests antineoplastic action of Ag NPs through apoptosis induction [39]. More or less the same effect is noticed in Ag NP-treated BEAS-2B cells when Ag NPs is gathered in endocytic vesicles genotoxic effects with increased ROS generation, formation of micronucleus, and enhanced DNA damage [40, 41].

\section{Effect of nanoparticles on genomic DNA (DNA fragmentation test)}

To further confirm the apoptotic event, a DNA ladder test was conducted in agarose gel. Vero and MCF-7 are treated with $100 \mu \mathrm{g} / \mathrm{ml}$ Ag NPS for $42 \mathrm{~h}$. Genomic DNA is extracted from the treated or control equivalent cultures and the results show that the DNA is
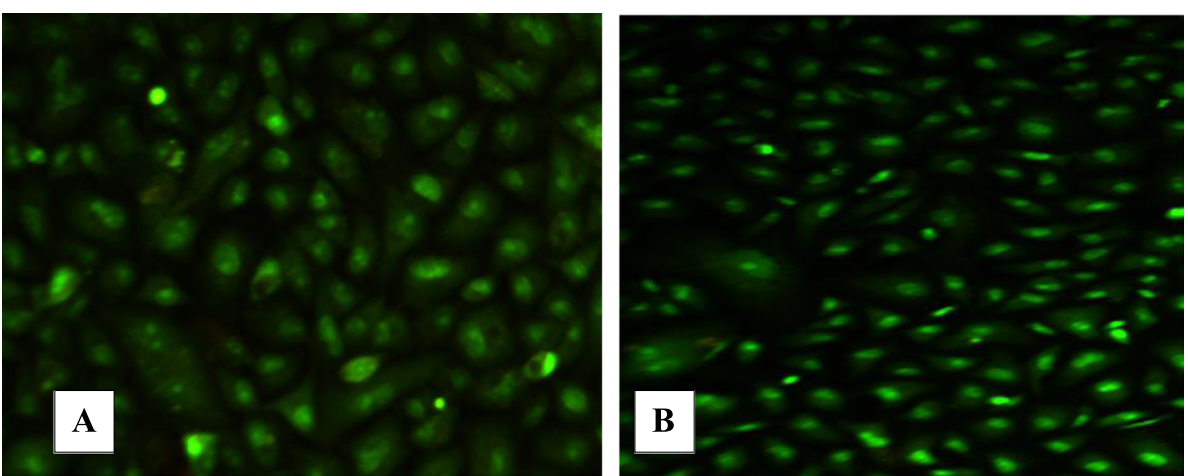

Fig. 3 Aciridine orange staining of Vero cell monolayers at control and NPs treated conditions. a Untreated cells. b Cells were treated with 100 $\mu \mathrm{g} / \mathrm{ml}$ of Ag NPs 

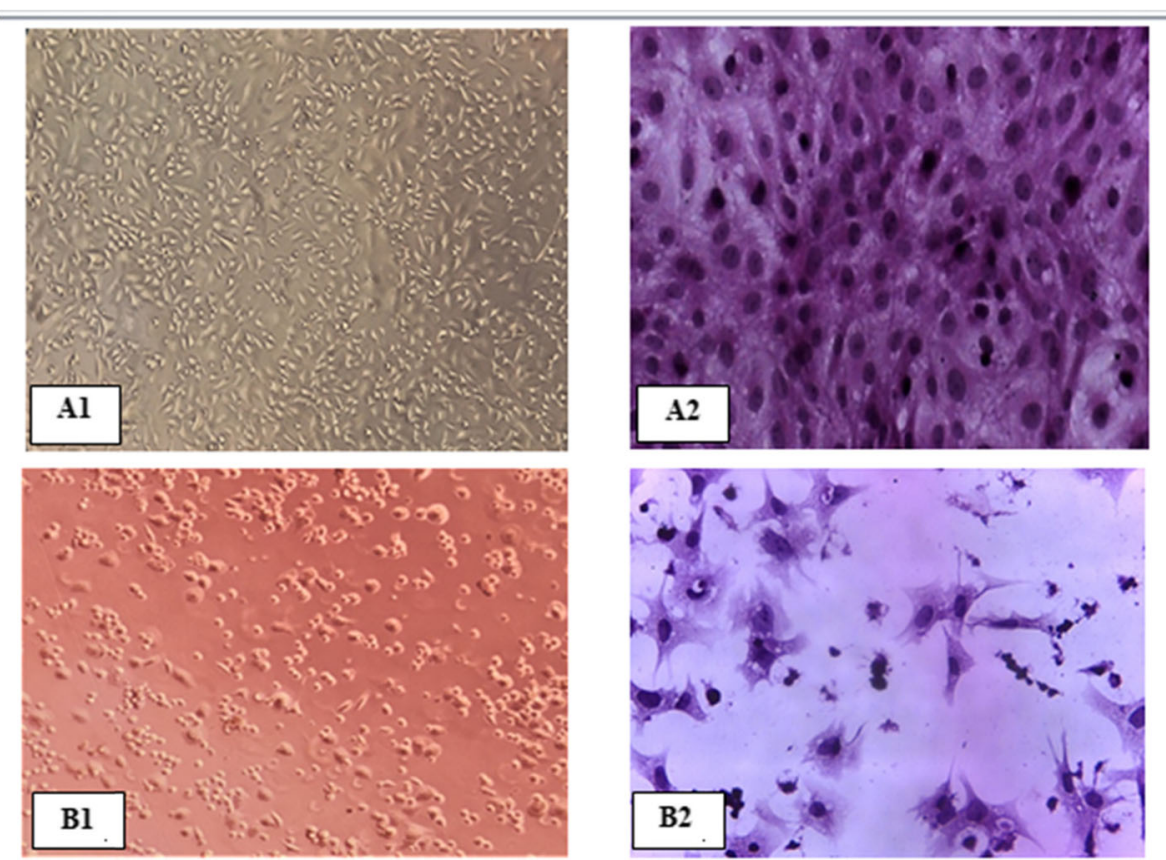

Fig. 4 Eosin and hematoxylin of staining MCF-7 cell line after 42 h. A1 Unstained control confluent monolayer. A2 Stained control confluent monolayer. B1 Unstained cells treated with $100 \mu \mathrm{g} / \mathrm{ml}$ of Ag NPS. B2 Stained cells treated with $100 \mu \mathrm{g} / \mathrm{ml}$ of Ag NPS

not affected and the genomic DNA is detected as one band at the top of the gel. No detectable fragmentation in agarose contradicts with the idea of having apoptosis due to the treatment with the NPS and with the results of Acridine orange staining. This might be due to the need for further processing that the cells need before extracting the genomic DNA such as treating cells with hypotonic solution. Rather, the genomic DNA showed the features of necrosis and spread DNA in the background is detected and this agrees with [42].

Another reason for not being able to detect the small fragments of genomic DNA [4] is that few cell lines including MCF-7 do not follow the DNA ladder pattern when they die $[43,44]$. Cell death without DNA fragmentation occurs for a reason that it might reduce the risk of transfer of oncogenic genes from an affected cell to an adjacent healthy cell or phagocytic cells [45].
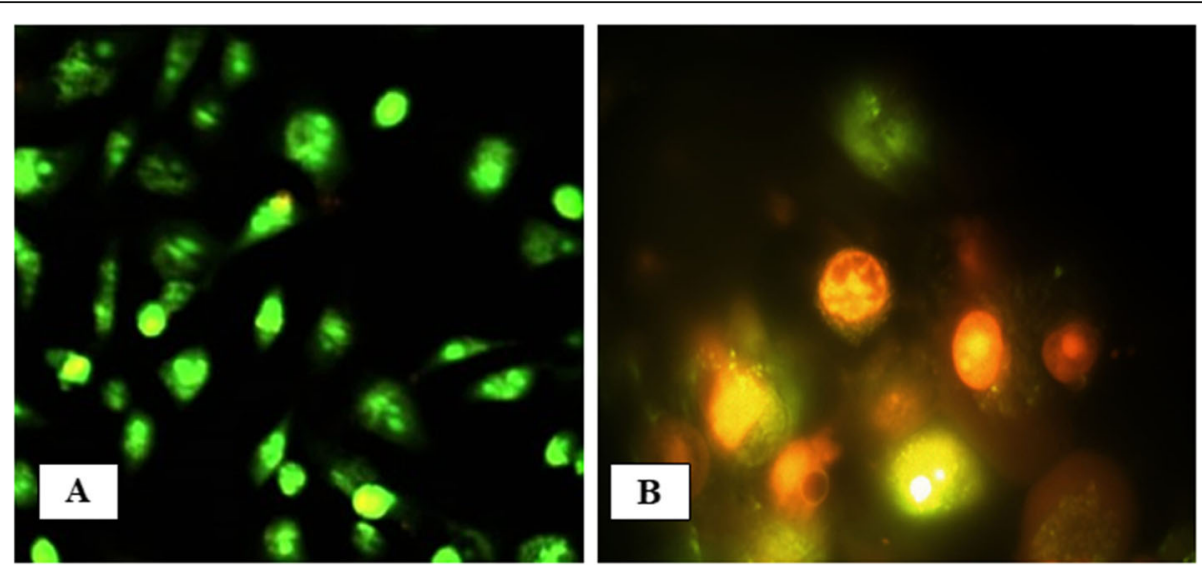

Fig. 5 Aciridine orange staining of MCF-7 cell monolayers at control and NP-treated conditions. a Untreated cells. b Cells were treated with 100 $\mu \mathrm{g} / \mathrm{ml}$ of Ag NPs 

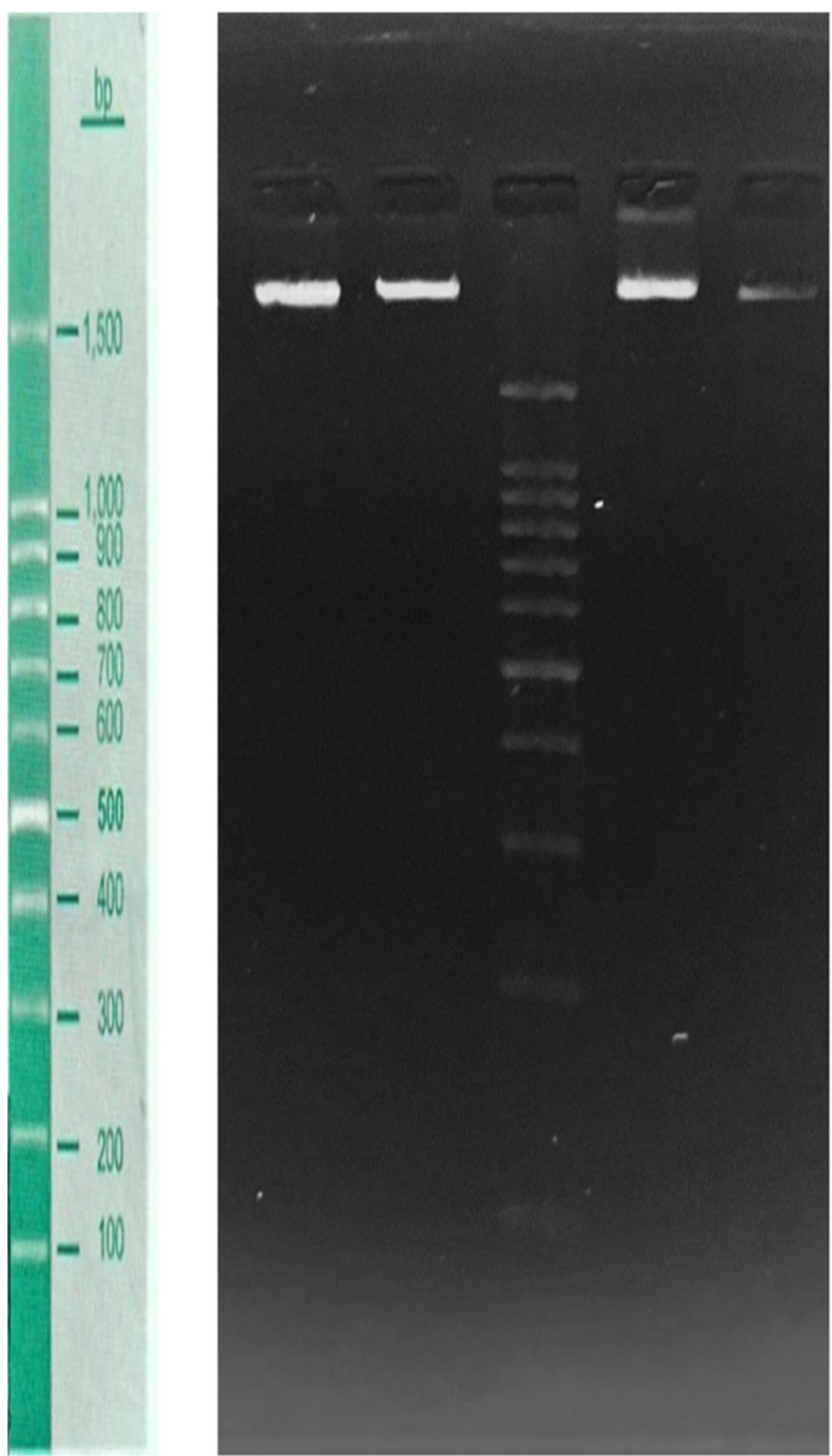

Fig. 6 DNA fragmentation test. Effect of Ag NPs on genomic DNA of MCF-7 and Vero cell lines. MCF-7 and Vero cell were seeded for $24 \mathrm{~h}$ and then treated with Ag NPs for $48 \mathrm{~h}$ or left without treatment as control. gDNA was extracted and electrophoresed at voltage of 75 for $1 \mathrm{~h}$ in $\% 1.5$ agarose. The bands were visualized under UV light. Left to right direction; lane 1: Ag NPs (100 $\mathrm{mg} / \mathrm{ml})$ Vero-treated samples; lane 2 DMSO Verotreated sample; lane 31500 bp DNA ladder; lane 4 MCF-7 DMSO-treated samples; lane 5 Ag NPs (100 mg/ml) MCF-7-treated sample

\section{Effect of nanoparticles on P53 expression}

To find out the effect of Ag NPs on the gene expression of apoptotic genes, Vero and MCF-7 cells are treated with $100 \mu \mathrm{g} / \mathrm{ml}$ for $48 \mathrm{~h}$. Ag NPs show a different effect on P53 expression since it increases its expression level in Vero treated cells but reduced it in MCF-7-treated cells. Ag NPs induce apoptosis in a P53-dependent pathway using the p53 inhibitor pifithrin $\alpha$ in human breast cancer cells [46, 47]. Continuous exposure of A549 cells to Ag NPs for $72 \mathrm{~h}$ reduces the gene expression of p53 
P53 gene expression in Ag NPS treated or untreated Vero and MCF-

7 cells

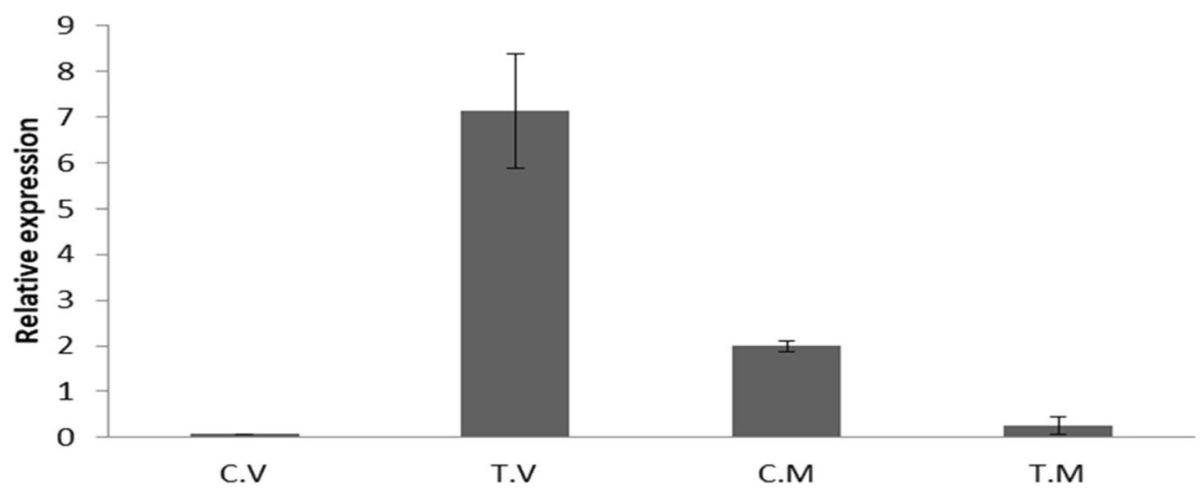

Fig. 7 P53 relative expression in MCF-7 and Vero cell treated or untreated with Ag NPs. Total RNA was extracted, reverse transcribed, and the synthesized DNA was used as a template for qPCR relative expression assay using SYBR green master mix. Data were analyzed by $\Delta \Delta C T$ s and normalized to ( $\beta$-actin) house-keeping gene $(t$ test $P<0.058,0.007)$

[48]. Starch-covered Ag NPs also increases the P53 gene expression in colon cancer cells. The only explanation for such reduction in MCF-7-treated samples can be the $48 \mathrm{~h}$ is a long-term exposure.

\section{Effect of nanoparticles on P21 expression}

The data showed that AgNPs treatment causes decrease in p21 expression in cancer cells. When treating normal cells (Vero) with Ag NPs, there is a higher expression in P21 compared to control. Consistent with the use of $\mathrm{Ag} \mathrm{NPs}$ and $\mathrm{Ag} / \mathrm{C} 225$ which are approximately $20 \mathrm{~nm}$ and which show an inhibitory effect on the proliferation of the human pharyngeal cancer cell line and the throat cancer cell line HEP-2 has been investigated. The inhibitory effect is a reflection of a decrease in the level of P21 in the cellular lines [49]. Continuous exposure of A549 cells reduces the gene expression of p21 [48]. Starchcovered Ag NPs are evaluated for efficacy on HCTI16 colon cancer cells. The data disagree with [46] since the treatment with AgNPs increases the P21 expression in the cancer cells to induce oxidative stress and DNA damage. In general, Ag NPs effect on gene expression is represented by the activation of p53, pErk1/2, and caspase-3 signaling, and downregulation of Bcl-2 and PARP-1 results in increasing caspase-3 activity. P21 overexpression in human cell lines

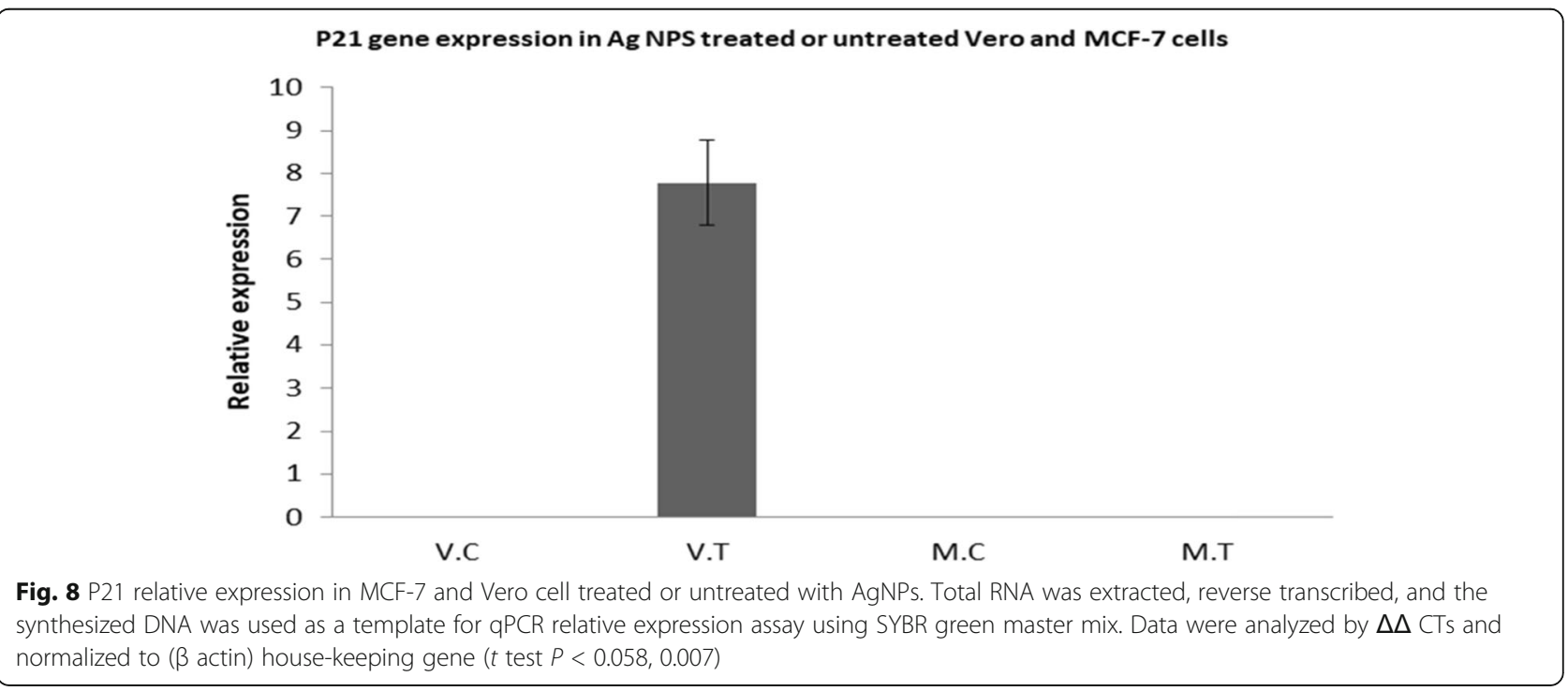




\section{PTEN gene expression in Ag NPS treated and untreated Vero and} MCF-7 cells

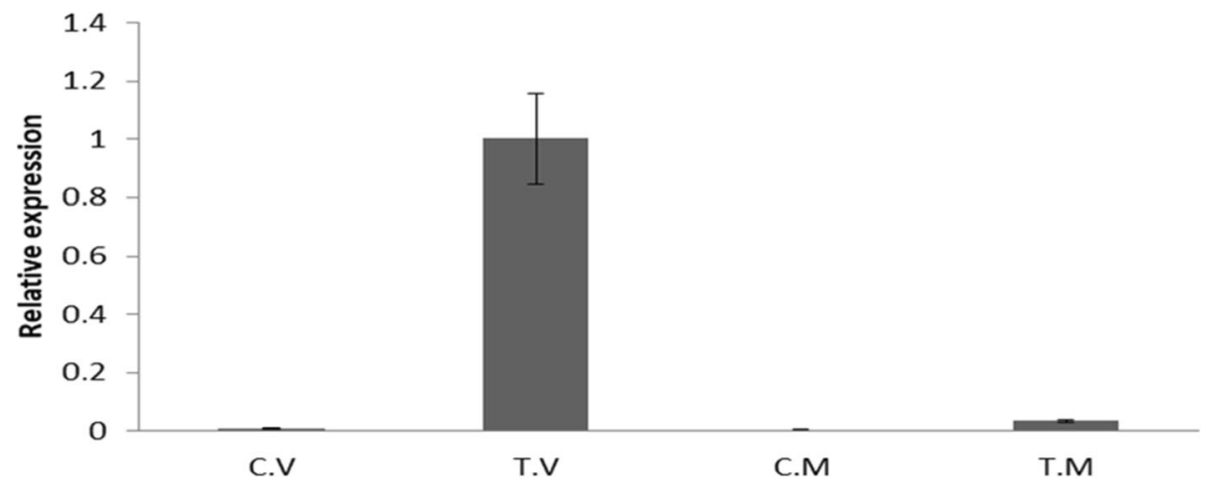

Fig. 9 PTEN relative expression in MCF-7 and Vero cell treated or untreated with Ag NPs. Total RNA was extracted, reverse transcribed, and the synthesized DNA was used as a template for GPCR relative expression assay using SYBR green master mix. Data were analyzed by $\Delta \Delta C T$ s and normalized to ( $\beta$-actin) house-keeping gene $(t$ test $P>0.05,0.07)$

induces the senescence and growth arrest. It inhibits the expression of genes that are implicated in in $\mathrm{mi}$ tosis and DNA replication and repair [50].

\section{Effect of nanoparticles on PTEN expression}

Interestingly, the data show an increase in PTENT expression in AgNP-treated Vero and MCF-7-treated cells but to a lower extent in the MCF-7 cells compared to the control. PTEN is antitumor protein and restoring the function of this protein suppresses the cancer cell proliferation and even the resistance to chemotherapy [40, 41]. The PTEN gene functions as a negative regulator of the PI3K/Akt pathway. Therefore, inhibition of this pathway stimulates programmed cell death in different types of cell lines [51]. So, it suggests it as a typical target to develop anticancer treatment strategies for cancer patients [52]. In addition, treatment with polymer lipid hybrid nanoparticles that restores the normal function of PTEN can enhance the apoptosis in prostate cancer [53].

\section{Conclusion}

The study was designed in order to evaluate the possibility of using the prepared AgNPs as antitumor therapy. In cytotoxicity testing, we found that Ag NPS are selective in killing cancerous cells but not the normal ones. Moreover, treating cells with Ag NPs, apoptosis was activated by activating the P21 and PTEN gene. In fact, PTEN increased gene expression (due to the treatment with AgNPs might have anti-tumor effect and suppressing the cell division). Fold in MCF7 or 3 fold in Vero cells compared to the control, PTEN abrogates the tyrosine kinases to control tumor cell invasion and metastasis. More detailed study is needed to use the AgNPs in experimental animals to analyze their effect in an in vivo system or even in other cell lines.

\section{Supplementary Information}

The online version contains supplementary material available at https://doi. org/10.1186/s43042-020-00120-1.

Additional file 1. Supplementary figure. AgNPs' characterization results.

\section{Abbreviations}

A549: Adenocarcinomic human alveolar basal epithelial cells; AC: Apoptosis cells; Ag NPs: Silver nanoparticles; Ag/C225: Ag conjugated to an epidermal growth factor receptor-specific antibody; AO: Acridine orange; BEAS-

2B: Normal human bronchial epithelium cell line; cDNA: Complementary deoxyribonucleic acid; CNTs: Carbone nanotubes; CT: Computer-assisted tomography; DMSO: Dimethyl sulfoxide solution; DNA: Deoxyribonucleic acid; EDTA: Ethylenediaminetetraacetic acid; ELISA: Enzyme-linked immunosorbent assay test; FBS: Fetal bovine serum; g: Gram; gDNA: Genomic deoxyribonucleic acid; G0/G1: Cell cycle arrest; GBM: Glioblastoma cell line; HCTI16: Human colon cancer cell line; HeLA: Human cervix adenocarcinoma; HEP-2: Human larynx carcinoma; HepG2: Human liver cancer cell line; MCF-7: Human breast cancer; MTT: Methyl thiazolium tetrazolium; NPs : Nanoparticles; PAC: Pre-apoptosis cells; PBS: Phosphate buffer saline; PH: Power of hydrogen; qPCR: Quantitative PCR; Real-time PCR: Real-time polymerase chain reaction; RNA: Ribonucleic acid; RPMI 1640: Rosswell Park Memorial Institute 1640 media; T.D.W: Tripled distilled water; TBE: Tris-borate buffer; TNF- a: Tumor necrosis factor alpha; UV : Ultraviolet; ZnS NPs: Zinc sulfide nanoparticles; ZnS-Ag NPs : Zinc sulfide-silver nanoparticles; $\mu \mathrm{g}$ : Microgram; $\mu \mathrm{m}$ : Micrometer

\section{Acknowledgements}

We would like to acknowledge professor dr Mazin Aunni Mahdi and Assistant research Walaa Saeed Abbas for their help in preparing and for the characterization of Ag nanoparticles//Department of Physics//College of science//Basrah University.

\section{Authors' contributions}

MS who is a master student at the Biology Department at College of Science has done all the experiments with the supervision and continuous advice that are provided by assistant professor ZA and professor AA as her supervisors, while Professor IA prepared the nanoparticles to start the work 
and analyzing their cytotoxic effects. All authors have read and approved the manuscript.

\section{Funding}

No fund was received for this work and was fully funded by the master student Mariam Hassan Sangour to but the reagents while she used the equipment that are provided at the Genetic Engineering Laboratory and Cell Culture Lab at the College of Science and Education/University of Basrah.

\section{Availability of data and materials}

All data are available whenever the journal asks for.

\section{Ethics approval and consent to participate}

Not applicable

\section{Consent for publication}

Not applicable

\section{Competing interests}

I certify that there is no actual or potential conflict of interest in relation to this article.

\section{Author details}

${ }^{1}$ Biology Department, College of Science, University of Basrah, Basra, Iraq. ${ }^{2}$ Department of Physics, College of Science, University of Baghdad, Baghdad, Iraq. ${ }^{3}$ Biology Department, College of Education for Basic Sciences, University of Basrah, Basra, Iraq

Received: 1 May 2020 Accepted: 2 December 2020

Published online: 05 February 2021

\section{References}

1. Mohseni N, Sarvestani FS, Ardestani MS, Kazemi-Lomedasht F, Ghorbani M (2016) Inhibitory effect of gold nanoparticles conjugated with interferon gamma and methionine on breast cancer cell line. Asian Pac J Trop Biomed 6(2):173-178

2. Qiao SL, Ma Y, Wang Y, Lin YX, An HW, Li LL, Wang H (2017) General approach of stimuli-induced aggregation for monitoring tumor therapy. ACS Nano 11(7):7301-7311

3. Boerman LM, Maass SW, van der Meer P, Gietema JA, Maduro JH, Hummel YM et al (2017) Long-term outcome of cardiac function in a populationbased cohort of breast cancer survivors: a cross-sectional study. Eur J Cancer 81:56-65

4. Walker PR, Sikorska M (1997) New aspects of the mechanism of DNA fragmentation in apoptosis. Biochem Cell Biol 75(4):287-299

5. Korkmaz N, Ceylan Y, Hamid A, Karadağ A, Bülbül AS, Aftab MN et al (2020) Biogenic silver nanoparticles synthesized via Mimusops elengi fruit extract, a study on antibiofilm, antibacterial, and anticancer activities. J Drug Deliv Sci Technol 59:101864

6. Nesrin K, Yusuf C, Ahmet K, Ali SB, Muhammad NA, Suna S, Fatih \$̧ (2020) Biogenic silver nanoparticles synthesized from Rhododendron ponticum and their antibacterial, antibiofilm and cytotoxic activities. J Pharm Biomed Anal 179:112993

7. Awasthi R, Roseblade A, Hansbro PM, Rathbone MJ, Dua K, Bebawy M (2018) Nanoparticles in cancer treatment: opportunities and obstacles. Curr Drug Targets 19(14):1696

8. Kahzad N, Salehzadeh A (2020) Green Synthesis of CuFe2O4@Ag Nanocomposite Using the Chlorella vulgaris and Evaluation of its Effect on the Expression of norA Efflux Pump Gene Among Staphylococcus aureus Strains. Biol Trace Elem Res 198, 359-370. https://doi.org/10.1007/s12011020-02055-5

9. Salehzadeh A, Naeemi S, Khaknezhad L, Moradi-Shoeili Z, Shandiz SAS (2018) Fe3O4/Ag nanocomposite biosynthesised using Spirulina platensis extract and its enhanced anticancer efficiency. IET Nanobiotechnol 13(7): 766-770

10. Zhang L, Gu FX, Chan JM, Wang AZ, Langer RS, Farokhzad OC (2008) Nanoparticles in medicine: therapeutic applications and developments. Clin Pharmacol Ther 83(5):761-769

11. Xing ZH, Wei JH, Cheang TY, Wang ZR, Zhou X, Wang SS et al (2014) Bifunctional pH-sensitive Zn (II)-curcumin nanoparticles/siRNA effectively inhibit growth of human bladder cancer cells in vitro and in vivo. J Mater Chem B 2(18):2714-2724

12. Xu L, Wang YY, Huang J, Chen CY, Wang ZX, Xie H (2020) Silver nanoparticles: synthesis, medical applications and biosafety. Theranostics 10(20):8996

13. De Matteis V, Cascione M, Toma CC, Leporatti S (2018) Silver nanoparticles: synthetic routes, in vitro toxicity and theranostic applications for cancer disease. Nanomaterials 8(5):319

14. Ong C, Lim JZZ, Ng CT, Li JJ, Yung LY, Bay BH (2013) Silver nanoparticles in cancer: therapeutic efficacy and toxicity. Curr Med Chem 20(6):772-781

15. Freshney RI (2015) Culture of animal cells: a manual of basic technique and specialized applications. Wiley, Hoboken

16. Luna LG (1968) Manual of histologic staining methods of the Armed Forces Institute of Pathology, 3rd edn. Blakiston Division, McGraw-Hill, New York

17. Makker A, Goel MM, Mahdi AA, Bhatia V, Das V, Agarwal A, Pandey A (2016) $\mathrm{PI3K} / \mathrm{Akt} / \mathrm{mTOR}$ signaling \& its regulator tumour suppressor genes PTEN \& LKB1 in human uterine leiomyomas. Indian J Med Res 143(Suppl 1):S112

18. Fidan-Yaylalı G, Dodurga Y, Seçme M, Elmas L (2016) Antidiabetic exendin-4 activates apoptotic pathway and inhibits growth of breast cancer cells. Tumor Biol 37(2):2647-2653

19. Chen LH, Cheyer AJ, Guzzoni DR, Gruber TR (2014) U.S. Patent No. 8,903,716. U.S. Patent and Trademark Office, Washington, DC

20. Andries V, Vandepoele K, Staes K, Berx G, Bogaert P, Van Isterdael G et al (2015) NBPF1, a tumor suppressor candidate in neuroblastoma, exerts growth inhibitory effects by inducing a G1 cell cycle arrest. BMC Cancer 15(1):391

21. Al-Sheddi ES, Farshori NN, Al-Oqail MM, Al-Massarani SM, Saquib Q, Wahab R, Siddiqui MA (2018) Anticancer potential of green synthesized silver nanoparticles using extract of nepeta deflersiana against human cervical cancer cells (HeLA). Bioinorg Chem Appl 2018

22. Choi YJ, Park JH, Han JW, Kim E, Jae-Wook O, Lee SY et al (2016) Differential cytotoxic potential of silver nanoparticles in human ovarian cancer cells and ovarian cancer stem cells. Int J Mol Sci 17(12):2077

23. Venugopal K, Rather HA, Rajagopal K, Shanthi MP, Sheriff K, Illiyas M et al (2017) Synthesis of silver nanoparticles (Ag NPs) for anticancer activities (MCF 7 breast and A549 lung cell lines) of the crude extract of Syzygium aromaticum. J Photochem Photobiol B Biol 167:282-289

24. Soenen SJ, Brisson AR, De Cuyper M (2009) Addressing the problem of cationic lipid-mediated toxicity: the magnetoliposome model. Biomaterials 30(22):3691-3701

25. Stroh C, Wang H, Bash R, Ashcroft B, Nelson J, Gruber H et al (2004) Singlemolecule recognition imaging microscopy. Proc Natl Acad Sci 101(34): 12503-12507

26. Lee B, Lee MJ, Yun SJ, Kim K, Choi IH, Park S (2019) Silver nanoparticles induce reactive oxygen species-mediated cell cycle delay and synergistic cytotoxicity with 3-bromopyruvate in Candida albicans, but not in Saccharomyces cerevisiae. Int J Nanomedicine 14:4801-4816

27. Dwivedi S, Siddiqui MA, Farshori NN, Ahamed M, Musarrat J, Al-Khedhairy AA (2014) Synthesis, characterization and toxicological evaluation of iron oxide nanoparticles in human lung alveolar epithelial cells. Colloids Surf B: Biointerfaces 122:209-215

28. Nicoletti I, Migliorati G, Pagliacci MC, Grignani F, Riccardi C (1991) A rapid and simple method for measuring thymocyte apoptosis by propidium iodide staining and flow cytometry. J Immunol Methods 139(2):271-279

29. Siddiqui MA, Saquib Q, Ahamed M, Farshori NN, Ahmad J, Wahab R et al (2015) Molybdenum nanoparticles-induced cytotoxicity, oxidative stress, G2/ $M$ arrest, and DNA damage in mouse skin fibroblast cells (L929). Colloids Surf B: Biointerfaces 125:73-81

30. El-Sonbaty SM (2013) Fungus-mediated synthesis of silver nanoparticles and evaluation of antitumor activity. Cancer Nanotechnol 4(4-5):73-79. https:// doi.org/10.1007/s12645-013-0038-3

31. Asharani PV, Hande MP, Valiyaveettil S (2009) Anti-proliferative activity of silver nanoparticles. BMC Cell Biol 10(1):65

32. Hsin YH, Chen CF, Huang S, Shih TS, Lai PS, Chueh PJ (2008) The apoptotic effect of nanosilver is mediated by a ROS-and JNK-dependent mechanism involving the mitochondrial pathway in NIH3T3 cells. Toxicol Lett 179(3): 130-139

33. Piao MJ, Kang KA, Lee IK, Kim HS, Kim S, Choi JY et al (2011) Silver nanoparticles induce oxidative cell damage in human liver cells through inhibition of reduced glutathione and induction of mitochondria-involved apoptosis. Toxicol Lett 201(1):92-100 
34. Rutberg FG, Dubina MV, Kolikov VA, Moiseenko FV, Ignat'eva EV, Volkov NM et al (2008) Effect of silver oxide nanoparticles on tumor growth in vivo. Dokl Biochem Biophys 421(1):191 Springer Science \& Business Media

35. Subbaiya R, Saravanan M, Priya AR, Shankar KR, Selvam M, Ovais M et al (2017) Biomimetic synthesis of silver nanoparticles from Streptomyces atrovirens and their potential anticancer activity against human breast cancer cells. IET Nanobiotechnol 11(8):965-972

36. Kanipandian N, Li D, Kannan S (2019) Induction of intrinsic apoptotic signaling pathway in A549 lung cancer cells using silver nanoparticles from Gossypium hirsutum and evaluation of in vivo toxicity. Biotechnol Rep 23: e00339

37. Plackal Adimuriyil George B, Kumar N, Abrahamse H, Ray SS (2018) Apoptotic efficacy of multifaceted biosynthesized silver nanoparticles on human adenocarcinoma cells. Sci Rep 8(1):14368

38. Lee YS, Kim DW, Lee YH, Oh JH, Yoon S, Choi MS et al (2011) Silver nanoparticles induce apoptosis and G2/M arrest via PKCC-dependent signaling in A549 lung cells. Arch Toxicol 85(12):1529-1540

39. Bin-Jumah M, Al-Abdan M, Albasher G, Alarifi S (2020) Effects of green silver nanoparticles on apoptosis and oxidative stress in normal and cancerous human hepatic cells in vitro. Int J Nanomedicine 15:1537-1548

40. Kim DH, Suh J, Surh YJ, Na HK (2017) Regulation of the tumor suppressor PTEN by natural anticancer compounds. Ann N Y Acad Sci 1401(1):136-149

41. Piro G, Carbone C, Carbognin L, Pilotto S, Ciccarese C, lacovelli R, Milella M, Bria E, Tortora G (2019) Revising PTEN in the Era of immunotherapy: new perspectives for an old story. Cancers 11(10):1525

42. Samarghandian S, Shabestari MM (2013) DNA fragmentation and apoptosis induced by safranal in human prostate cancer cell line. Indian J Urol 29(3):177

43. Oberhammer F, Wilson JW, Dive C, Morris ID, Hickman JA, Wakeling AE et al (1993) Apoptotic death in epithelial cells: cleavage of DNA to 300 and/or $50 \mathrm{~kb}$ fragments prior to or in the absence of internucleosomal fragmentation. EMBO J 12(9):3679-3684

44. Walker PR, Leblanc J, Carson C, Ribecco M, Sikorska M (1999) Neither caspase-3 nor DNA fragmentation factor is required for high molecular weight DNA degradation in apoptosis. Ann N Y Acad Sci 887(1):48-59

45. De la Taille A, Chen MW, Burchardt M, Chopin DK, Buttyan R (1999) Apoptotic conversion: evidence for exchange of genetic information between prostate cancer cells mediated by apoptosis. Cancer Res 59(21): 5461-5463

46. Gurunathan S, Park JH, Han JW, Kim JH (2015) Comparative assessment of the apoptotic potential of silver nanoparticles synthesized by Bacillus tequilensis and Calocybe indica in MDA-MB-231 human breast cancer cells: targeting p53 for anticancer therapy. Int J Nanomedicine 10:4203

47. Gopinath P, Gogoi SK, Sanpui P, Paul A, Chattopadhyay A, Ghosh SS (2010) Signaling gene cascade in silver nanoparticle induced apoptosis. Colloids Surf B: Biointerfaces 77(2):240-245

48. Blanco E, Kessinger CW, Sumer BD, Gao J (2009) Multifunctional micellar nanomedicine for cancer therapy. Exp Biol Med 234(2):123-131

49. Zhang Y, Lu H, Yu D, Zhao D (2017) "AgNPs and Ag/C225 Exert Anticancerous Effects via Cell Cycle Regulation and Cytotoxicity Enhancement". J Nanomaterials vol 2017, Article ID 7920368, 10 pages https://doi.org/10.1155/2017/7920368

50. Chang BD, Watanabe K, Broude EV, Fang J, Poole JC, Kalinichenko TV, Roninson IB (2000) Effects of p21Waf1/Cip1/Sdi1 on cellular gene expression: implications for carcinogenesis, senescence, and age-related diseases. Proc Natl Acad Sci 97(8):4291-4296

51. Lei H, Furlong PJ, Ra JH, Mullins D, Cantor R, Fraker D, Spitz FR (2005) AKT activation and response to interferon- $\beta$ in human cancer cells. Cancer Biol Ther 4(7):709-715

52. Nakatani K, Sakaue H, Thompson DA, Weigel RJ, Roth RA (1999) Identification of a human Akt3 (protein kinase B $\gamma$ ) which contains the regulatory serine phosphorylation site. Biochem Biophys Res Commun 257(3):906-910

53. Islam MA, Xu Y, Tao W, Ubellacker JM, Lim M, Aum D et al (2018) Restoration of tumour-growth suppression in vivo via systemic nanoparticle-mediated delivery of PTEN mRNA. Nat Biomed Eng 2(11):850-864

\section{Publisher's Note}

Springer Nature remains neutral with regard to jurisdictional claims in published maps and institutional affiliations.

\section{Submit your manuscript to a SpringerOpen ${ }^{\circ}$ journal and benefit from:}

- Convenient online submission

- Rigorous peer review

- Open access: articles freely available online

High visibility within the field

- Retaining the copyright to your article

Submit your next manuscript at $\boldsymbol{\nabla}$ springeropen.com 